\title{
Research on Cultivation of Humanistic Quality in University English Teaching
}

\author{
Li Yifei \\ Bohai University, Jinzhou, Liaoning, China, 121013 \\ liyifei163.com
}

Keywords: humanistic quality; university English teaching

\begin{abstract}
Currently, the teachers and students in universities attach importance to the professional learning, while ignoring the humanistic education. This paper gives the present situation of lack of humanistic quality in university English teaching, then analyzes the reasons of the phenomenon, and finally gives the suggestions such as changing teaching ideology, using classroom teaching, developing second classroom and enhancing teachers' quality to improve humanistic quality in university English teaching.
\end{abstract}

\section{Concept of Humanistic Quality}

"Humanities" is a concept that covers a wide range of things. In the modern sense, "humanities" mainly refers to the social morality, value idea, aesthetic taste and thinking mode formed in the process of social development. The essence of the humanistic quality education lies in the cultivation of humanistic spirit. Humanistic quality education is the education process. It aims to mankind in the long social activities by the accumulation of spiritual wisdom to cultivate people, educating people, emphasize the value of human moral spirit, attention on the goodness and beauty understanding, guide people to seek the truth, from goodness and beauty, make the person can insight into the life of the purpose and significance of, find the correct way of life. Simply speaking, the "Humanistic Quality Education" means the education to cultivate students' humanistic spirit and to improve students' humanistic quality.

\section{Present situation of lack of Humanistic Quality in University English Teaching}

At present, the universities always overemphasized the importance of the professional learning due the pressure of employment. However, at the same time, the humanity quality, which is also necessary in the employment and the life, is ignored. Universities should attach importance to the cultivation of students' humanistic knowledge and improve the humanistic quality of the university students, and put the idea to carry out the teaching of the humanities, especially as learning to university English Teaching in the language of western countries, to enable the university to cultivate graduates to become the all-round development of talent, not only has the expertise to solve practical problems, but also the basic culture. Learn the language at the same time, can open view of life, expand the space of the mind, the subject of a solid knowledge, widespread interest hobby, rich social experience, with good humanistic spirit, but also has a higher realm of life. Traditional university English teaching, teaching method is relatively simple, the teacher, students listen, take notes, the word back, do homework, heuristic teaching, participation type teaching difficult, active participation of students lack. Most of the teachers in universities are engaged in the teaching progress and plan. The teachers and students are busy with the examination of the four and six levels. However, graduates face is employment and employment, graduate studies and reality. The job market of students English proficiency requirements is relatively high. Therefore, change the English teaching pertinence, transform teaching means, improve the depth and breadth of English teaching, effectively improve the students' practical ability to use the language, has become the mission of the language educators. Due to the deficiency of good English language practice atmosphere and application environment, students' humanistic quality is comparatively not so good. 


\section{Analysis of reasons of lack of Humanistic Quality in University English Teaching}

\section{On the Teaching Ideology Level}

One-sided understanding of university English teaching objectives has blocked the penetration of humanistic education. In January 2004, the Ministry of Education released the University English curriculum requirements and points out that the goal of university English teaching is: training students' English comprehensive application ability especially the ability of listening and speaking, so that they are able to use English effectively for oral and written communication in the future work and social intercourse, and enhance their ability of autonomous learning, improve their comprehensive cultural literacy, in order to meet the needs of China's social development and international exchanges. Goal of University English teaching has three levels: one is to teach the students only know the content of the teaching material will only understand language in context of textbooks; second is the student learning materials can master the language, and can skillfully use of language; the third is the students not only learn how to use the language, but also deep feelings to reflect the humanistic spirit in the teaching material between the lines, the soul by the shock, and consciously take the initiative to the implement this spirit into their daily behavior in. But at present, the teachers in the teaching practice for teaching and learning, the students learn the present situation shows that we are still in the first level. The narrow understanding of the objective of university English teaching of teachers and students leads to the difficulty of infiltration of humanistic education in university English teaching.

\section{On the Students' Reality Level}

The student schoolwork burden results in the phenomenon that students are unable to carry out humanistic education. University English teaching material is not only rich in content, but also in various forms. But at the same time, the burden is also growing. Teachers should complete explanation of the text and do the exercises, listening, reading training task of teaching hours are limited, the humanistic spirit in the teaching materials of mining and understanding of the need to a lot of discussion between the teacher and students and teachers guide, more difficult to implement. Students tend to get tired of learning, to cope with exams, to put others in the. This approach inhibits the development of students, and also cannot cultivate the human spirit of students.

\section{On the Teachers' Quality Level}

It's another reason of the lack of humanistic quality in university English teaching that the teachers and students humanistic foundation is weak. They are unable to highlight the humanities education. Nowadays, University English teachers are basically a "product" of the traditional examination oriented education, which has obvious limitations in the field of vision and human knowledge. Despite this limitation because of individual teacher's self-development and self-enrichment and have to make up for, but it is difficult to have a breakthrough change, directly affects the teacher's understanding of the humanistic knowledge and understanding, thereby affecting the penetration of humanistic spirit in the teaching process. And now the university students have a wide range of information sources, but it is not much involved in human knowledge. They tend to blind, emotional, utilitarian and vanity to seize the opportunity to sneak in, occupation their young hearts, affecting their experience and manners of the humanistic spirit, directly affect the humanistic education in university English Teaching in the penetration. In addition, teachers and students lack of exchanges and dialogue and the student assessment method is not scientific also hinders to penetrate the humanities education in university English teaching.

\section{Suggestions of Improving Humanistic Quality in University English Teaching}

\section{Change Teaching Ideology}

Teachers should further study and research "University English Teaching Syllabus" to have a good command of the specific indicators of the syllabus. To establish a skill culture is the tools of thought, the ultimate goal of learning English is clear is communicating with others in English and get the related knowledge and information, consciously in the teaching practice on Cultivation of students' language ability, adhere to the classroom teaching with students as the center, education 
and teaching to "learn learning as the center", using English teaching gradually promote the all-round improvement of the quality of students. Teachers should find and confirm the loss of humanistic quality of university students, make clear the current ideological trends of university students and carry out classification analysis, determine the direction of education. The students questions, analysis and discussion, summary etc. inspiration and guidance, training students to use creative thinking to the habit of independent thinking. Teachers should change passive acceptance to participate actively and change "knowledge teaching" to "inspire innovation".

\section{Use Classroom Teaching}

University English teachers should give full play to the role of the classroom teaching of human education. First of all, teachers should establish the concept of "learn by doing" and to reform the teaching methods, according to the specific circumstances of the student status, textual features, such as the corresponding teaching methods and models, such as "task method" "case law" "role", "Situational Method" to solve the contradiction method "'" cultural comparison method "and so on, so that students learn music, love to learn and learn something. Based on Humanistic Education in the design of classroom activities, to study how to from the individual work, pair work and group work in three aspects of design of classroom teaching activities, enable students in classroom activities, learn to cooperate with others and handle all kinds of relationships, emotional cultivation. The students sense of humanistic topics of interest as the starting point, around the humanities education of comprehensive training of language skills to teach knowledge, especially the need to train the attitude, emotion and values such as digging, imperceptibly fusion, penetration in the process of learning the curriculum subjects, not only exercise the students use English thinking ability, promoting listening and development capacity, improve teacher-student, student relationship, inspire the mind of students, improve their humanities accomplishment. Effective humanistic teaching methods should include discussion, dialogue, inspiration, practice and reflection, and so on. This requires teachers to adopt flexible and diverse teaching methods, focus on inspiration and guidance. The classroom must be in-depth discussion of content, in order to understand its deep cultural connotation. According to the text, design different teaching methods, the students practice as the main body and the teacher to explain is the dominant organic combination, to enable students to truly become the participants and practitioners of the interactive language activities. Teacher questioning the heuristic, practice, review and a variety of ways, teaching by using double dialogue, group discussion, role play, topic discussion, simulation activities, avoid the teaching of single in English teaching. Teachers can use many means to strengthen the students' aesthetic and humanistic consciousness, such as the aggressive use of computer multimedia and network technology and other modern means of teaching. Teachers should make full use of multimedia teaching courseware in English teaching to help students to understand the humanistic quality from different angles.

\section{Develop Second Classroom}

Teachers should also seek various forms of humanistic quality education forms while the classroom teaching is not enough. Develop the English second classroom to carry out various forms of outreach activities, to create a good English practice and language background atmosphere, to introduce to the students the knowledge of Humanities make it become an important link in the English Teaching. Teachers should be organized to carry out English broadcasting, foreign cultural customs, film and other teaching activities, the campus English corner and the form of a variety of English competition, etc. At the same time, the modern means of science and education, so that students in these various forms of activities gradually realize and improve the work and life of confidence and courage, form a solid academic attitude, noble life philosophy to educational purposes. School to for students to create a positive use of English stage, such as organizing English recitation contest, English poetry recitation contest, English speech game, the establishment of British and American film and Television Appreciation Society, English club and other associations. Teachers should according to the characteristic of students, to carry out training of application ability of competitions, such as encouraging students majoring in management case analysis, the computer professional students of English program design, international trade professional students 
of business negotiations. Teachers should use all kinds of social activities to improve students' comprehensive humanistic quality, such as the establishment of long-term cooperative relationship.

\section{Enhance Teachers' Quality}

The implementation of humanistic education in university English teaching requires that the English teachers have a higher humanistic quality. University teachers with deep humanistic quality are the prerequisite for achieving the goal of university education, cultivating comprehensive applied talents, and promoting the harmonious development of students. The humanistic quality of the teachers is the humanistic spirit of profound humanistic knowledge, noble morality, and the pursuit of the value of life. Enhance the sense of mission and responsibility and establish a correct view of students and the students' survival and development of the education concept. Hold the academic forum regularly, carry on the academic exchange, and improve the teacher's personal scientific research ability and comprehensive quality. Also encourages teachers to participate in all kinds of English learning seminars, to broaden their horizons, improve the overall quality. As an English teacher, we should try our best to create a good English environment for the students. Teachers should try to make the classroom language English, and effectively organize students to carry out a variety of teaching activities. With teachers' excellent social personality, students' humanistic quality can be improved more quickly.

\section{References}

[1] Cao Fengjing. Cultivation of Humanistic Quality in College English Teaching. J. Journal of Liaoning Technical University (Social Science Edition). 2014(5):320-324.

[2] Shan Chunxin. On Humanistic Quality Education in English Teaching. J. Journal of Qiongzhou University.2011 (1):67-68.

[3] Li Fang. AStudyontheCultivationofHumanisticQualitiesinEnglishTeachinginHigherVocational Colleges. J. Journal of Ningbo Institute of Education. 2013(5): 75-77. 